\title{
Repeatability of events during spontaneous and gonadotrophin-induced oestrus in bitches
}

\author{
G. C. W. England and W. E. Allen \\ Obstetrics Unit, Royal Veterinary College, University of London, Hawkshead Lane, North Mymms, \\ Hatfield AL9 7TA, UK
}

\begin{abstract}
Summary. Oestrus induction using equine chorionic gonadotrophin and human chorionic gonadotrophin was successful in five out of six bitches, although the first day of increased plasma progestagen concentration differed considerably between bitches. Induced oestrous periods differed from spontaneous cycles in the timing of vaginal epithelial cell cornification; plasma oestrogen concentrations were generally greater and progestogen concentrations were less in induced cycles. These results suggest that this schedule of oestrus induction would not be suitable for allowing mating on a predetermined day.
\end{abstract}

Keywords: oestrus induction; gonadotrophins; progestogen; oestrogen; oestrus; dog

\section{Introduction}

The interoestrous interval of bitches is 31 weeks, on average (Rowlands, 1950; Christie \& Bell, 1971). Bitches with longer than average interoestrous intervals and those that are slow to reach puberty (Chakraborty et al., 1982) have reduced chances of becoming pregnant. The development of a method to induce oestrus effectively and predictably in bitches would be advantageous, especially in a breeding establishment where a continuous supply of pups is required.

Equine and human chorionic gonadotrophins were first used for oestrus induction by Scorgie (1939); many other workers have used these preparations in different regimens and doses with varying success (Greenblatt \& Pund, 1941; Bell \& Christie, 1971; Wright, 1972; Jones et al., 1973; Thun et al., 1977; Archbald et al., 1980; Wright, 1980; Allen, 1982; Barta et al., 1982; Wright, 1982; Toniollo \& Ferreira, 1984; Nakao et al., 1985). Others have attempted the induction of oestrus using oestrogens alone or in combination with gonadotrophins (Papanicolaou \& Blau, 1927; Hancock \& Rowlands, 1949; Renton et al., 1981; Chakraborty et al., 1982; Ishihara et al., 1982; Moses \& Shille, 1988) and a variety of other compounds (Einer-Jensen, 1967; Auskova et al., 1974; Carter, 1980; Vanderlip et al., 1987; Cain et al., 1989; Concannon, 1989; Shille et al., 1989).

The success of induction differs between reports, even when similar regimens are used. There are problems in comparing results because most workers used few animals and definitions of anoestrus based upon behavioural and cytological information, and made no distinction between early and late anoestrus. Some workers used normal bitches, but others used bitches with prolonged anoestrus, and the criteria for success were different, e.g. ovulation, pregnancy or whelping.

The feasibility of mating on a fixed day following the initiation of an oestrus induction regimen was investigated and the findings were compared with spontaneous oestrus in the same bitches.

\section{Materials and Methods}

The method of Arnold et al. (1989) was used to induce oestrus because the reported plasma hormone concentrations resembled those of natural oestrus. Six clinically normal crossbred bitches were used for the study; each was $3-4 \cdot 5$ months from the end of the previous oestrus, and vaginal smears were typical of anoestrus. 
Oestrus induction was attempted in each bitch with five daily subcutaneous injections of 20 iu equine chorionic gonadotrophin (Folligon: Intervet UK Ltd, Cambridgeshire, UK) $/ \mathrm{kg}$ and $500 \mathrm{iu}$ of human chorionic gonadotrophin (Chorulon: Intervet UK Ltd, Cambridgeshire, UK) given intramuscularly on the fifth day.

Heparinized blood samples were collected from the jugular vein for oestrogen and progestagen determination by radioimmunoassay. Total unconjugated oestrogens were measured by radioimmunoassay as described by Challis et al. (1971) using an antiserum that mainly cross-reacted with oestradiol-17- $\beta(100 \%), 6$ - $\alpha$ hydroxyoestradiol $(82 \%)$, oestradiol-17- $\alpha(5 \cdot 3 \%)$, oestrone $(4.8 \%)$ and oestriol $(1.3 \%)$. The assay detection limit was $5 \mathrm{pg} / \mathrm{ml}$ and the interassay coefficient of variation at $25 \mathrm{pg} / \mathrm{ml}$ was $6.8 \%$; at $250 \mathrm{pg} / \mathrm{ml}$ it was $19.3 \%$. Progestagens were measured as progesterone by the radioimmunoassay method described by Cockrill \& Allen (1978). The antiserum cross-reacted mainly with progesterone $(100 \%)$, 11- $\alpha$-hydroxyprogesterone $(85 \%)$, 17- $\alpha$-hydroxyprogesterone $(12 \cdot 5 \%)$, 5- $\beta$-pregnane-3,20dione $(12 \cdot 5 \%)$, 5- $\alpha$-pregnane-3,20-dione $(3 \%)$, 5- $\beta$-pregnane-3- $\beta$-ol-20-one $(1 \cdot 7 \%)$, 11 -deoxycorticosterone $(1 \cdot 1 \%)$ and 5- $\alpha$-pregnane-3- $\beta$-ol-20-one $(1 \%)$. The assay detection limit was $0.05 \mathrm{ng} / \mathrm{ml}$ and the interassay coefficient of variation at $0.63 \mathrm{ng} / \mathrm{ml}$ was $35 \%$ and at $1.79 \mathrm{ng} / \mathrm{ml}$ was $16.8 \%$.

Vaginal smears were collected daily. The smears were stained with M\&D Diff-Quik (American Hospital Suppliers, Didcot, Oxfordshire, UK) and cytology was examined. The percentage of epithelial cells assessed as cornified using this stain was calculated as the 'cornification index' (van der Holst \& Best, 1976). When examined in this manner, the number of cornified cells increases in oestrus and, after a small decrease, increases again. This double cornification peak has been reported previously (van der Holst \& Best, 1976; England \& Allen, 1989).

The degree of vulval swelling was scored visually on a scale between 0 (anoestrus) and 5 (maximal vulval oedema). The behavioural response to teasing with a male was scored as 0 , aggression; 1 , lack of interest; 2 , playing; 3 , teasing behaviour by the bitch; 4 , tail deviation; and 5 , standing to be mounted.

Approximately 10 days after the onset of metoestrus (following induction), as assessed by vaginal cytology, the ovaries were removed at laparotomy. They were fixed in $10 \%$ buffered formal saline; histological sections were then cut and stained with haematoxylin and eosin.

All variables except metoestrous ovarian histology had been previously recorded for all the bitches during a spontaneous oestrous cycle. The timing of the events of the induced cycles (proestrus and cornification) were compared with the spontaneous cycles to examine their repeatability. Each event was timed from the onset of hormone therapy (Day 1) or the onset of spontaneous proestrus (Day 1) for comparison. The length of proestrus was defined as the period from the onset of vulval swelling to the onset of standing oestrus.

However, it has been shown previously (England et al., 1989) that the clinical events of spontaneous cycles may not be repeatable in the same bitch, so that comparisons between spontaneous and induced cycles are difficult to make. To overcome this problem, cycles were also compared relative to the first day that plasma progestagen concentration increased above $0.9 \mathrm{ng} / \mathrm{ml}$; this was designated Day 1 .

Statistical analysis of the results was performed using the Student's $t$ test; values were considered significant when $P<0 \cdot 05$. Values are given as means \pm s.d.

\section{Results}

The behavioural manifestations of oestrus were successfully induced in five of the six bitches (Fig. 1). Histological examination of the ovaries of these five bitches demonstrated 3-6 corpora lutea within each ovary. These were characterized by thick, infolded luteal tissue with small, central, fluid-filled cavities. In the remaining bitch, behavioural oestrus was not induced and there was no significant change in plasma hormones or vaginal cytology; ovarian histology was not examined. This bitch had the shortest interval ( 3 months) from the previous oestrus. With the exception of the onset of the rise in plasma progestagen concentrations, the timing of events following the beginning of hormone therapy was consistent within 4 days (Table 1).

When spontaneous and induced oestrous periods were compared relative to the first day of increased plasma progestagen, the onset of the first peak of cornified epithelial cells occurred significantly earlier when oestrus was spontaneous (Table 2). The greatest difference between spontaneous and induced cycles was the range of each event when related to the first day of increased plasma progestagen. Variations were greater during induced cycles for all events, with the exception of the first day of standing oestrus.

The maximum percentage second peak cornification during spontaneous cycles was $93 \pm 5 \cdot 1$ (s.d.) and for induced cycles was $86 \pm 3.9$ (s.d.); these values were significantly different $(P<0.05)$.

There was considerable variation in oestrogen and progestagen concentrations between spontaneous cycles (Fig. 1). In the induced cycles, oestrogen concentrations increased after the administration of equine chorionic gonadotrophin and were greater than those of the spontaneous cycles in three of the five bitches. Progestagen concentrations were always low when compared with the 


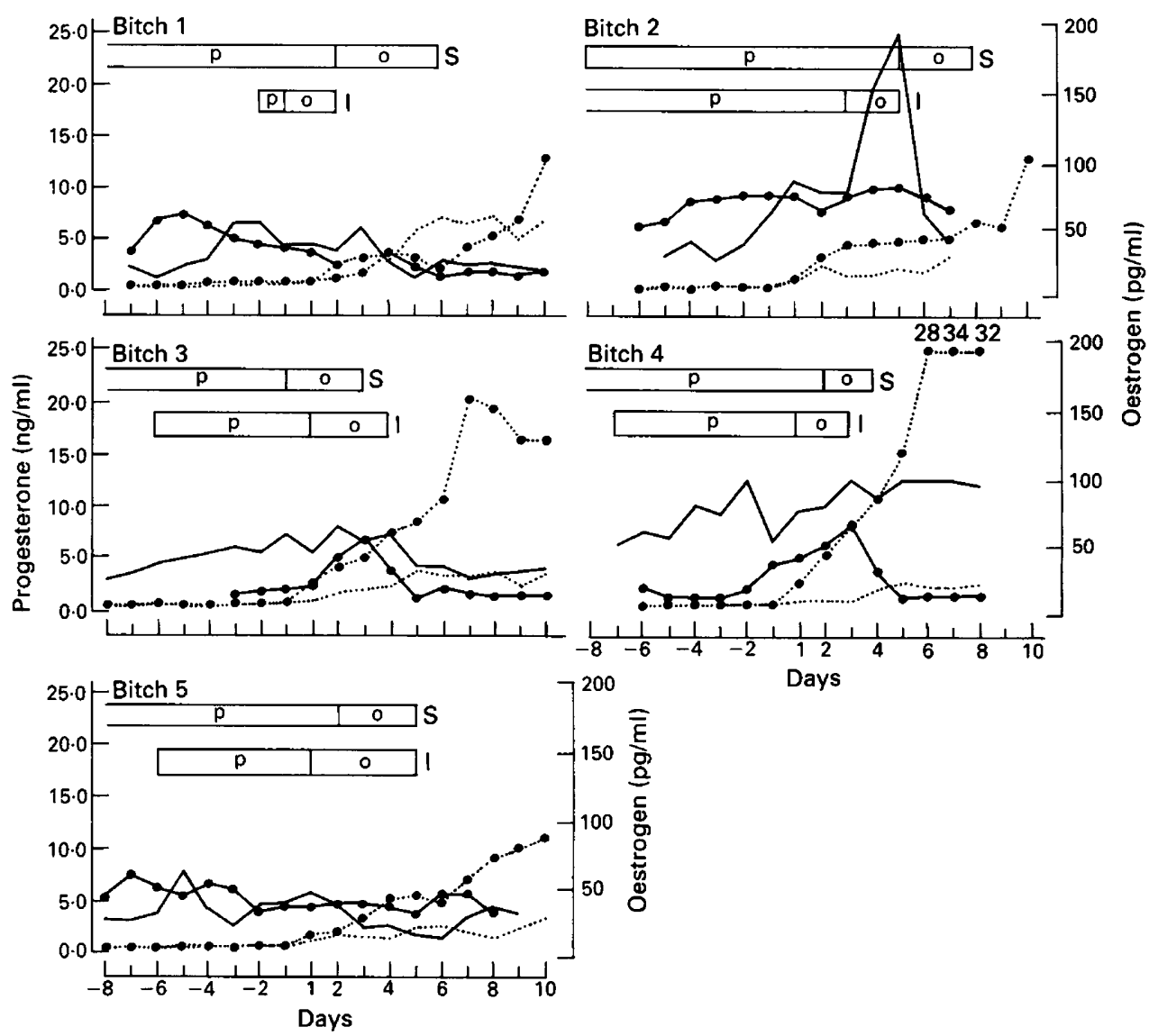

Fig. 1. Plasma hormone concentrations during spontaneous (S) and induced (I) cycles in five bitches relative to the first day of increased plasma progestagen concentration. Bars represent periods of proestrus $(\mathrm{p})$ and oestrus (o); oestrogen $(-0-)$ and progesterone $(\cdots \cdots)$ in $S$ cycles; oestrogen $(-)$ and progesterone $(\cdots)$ in I cycles.

Table 1. Timing of events of induced oestrus measured from the onset of hormone therapy for five bitches

\begin{tabular}{lccc}
\hline & $\begin{array}{c}\text { Mean } \\
\text { (days) }\end{array}$ & \pm s.d. & $\begin{array}{c}\text { Range } \\
\text { (days) }\end{array}$ \\
\hline Onset of vulval swelling & 6.0 & 1.7 & $4-8$ \\
$\quad$ Length of proestrus & 7.4 & 1.5 & $5-9$ \\
Onset of standing oestrus & 12.0 & 1.9 & $10-14$ \\
$\quad$ Length of standing oestrus & 5.2 & 1.3 & $4-7$ \\
First cornification peak & 12.2 & 1.6 & $10-14$ \\
Second cornification peak & 14.5 & 1.9 & $12-16$ \\
First day of increased progestagen & 12.0 & 3.5 & $9-18$ \\
\hline
\end{tabular}

spontaneous cycles in the same animals. Mean progestagen concentrations 5 days after the initial rise were $7 \cdot 4 \pm 4.6$ and $3 \cdot 2 \pm 1 \cdot 5$ (s.d.) $\mathrm{ng} / \mathrm{ml}$ for spontaneous and induced cycles, respectively; these values were not significantly different. 
Table 2. Comparison of the timing of events of spontaneous (S) and induced (I) oestrus in five bitches. Values are the mean number of days before $(-)$ or after $(+)$ the first day of increased plasma progestagen concentration

\begin{tabular}{lcccc}
\hline & & $\begin{array}{l}\text { Mean } \\
\text { (days) }\end{array}$ & \pm s.d. & $\begin{array}{l}\text { Range } \\
\text { (days) }\end{array}$ \\
\hline Onset of vulval swelling & S & $-9 \cdot 0$ & $1 \cdot 4$ & -11 to -8 \\
& I & $-6 \cdot 0$ & $3 \cdot 3$ & -11 to -2 \\
Onset of standing oestrus & S & $+1 \cdot 8$ & $3 \cdot 2$ & -1 to +5 \\
& I & $+0 \cdot 8$ & $3 \cdot 2$ & -1 to +3 \\
1st cornification peak & S & $-2 \cdot 3^{*}$ & $0 \cdot 9$ & -1 to -3 \\
& I & $+1 \cdot 4^{*}$ & $3 \cdot 6$ & -5 to +4 \\
2nd cornification peak & S & $+2 \cdot 5$ & $1 \cdot 3$ & +1 to +4 \\
& I & $+3 \cdot 3$ & $3 \cdot 6$ & -2 to +5 \\
\hline
\end{tabular}

*Significantly different $P<0.05$.

\section{Discussion}

Oestrus was induced in five of the six bitches as determined by behaviour and the presence of corpora lutea. The bitch that did not respond had the shortest interval from the previous oestrus. The time of occurrence of the onset of vulval swelling, the length of proestrus, the onset and length of standing oestrus and the occurrence of vaginal cytological cornification were similar between animals after hormone administration, but the onset of increased plasma progestagen concentrations (Days 9-18), presumably reflecting the timing of ovulation, was very variable. This would not allow for the mating day to be predetermined and confirms the differences that can occur between hormonal indices and clinical events (Wildt et al., 1978).

The timing of the onset of proestrus, the onset of standing oestrus and the second peak of vaginal cell cornification was not statistically different between induced and spontaneous cycles when they were related to plasma progestagen concentrations. However, only a few animals were used and when the cycles were induced there was a considerable range for each event. These observations suggest that, when oestrus is induced in bitches, the timing of the associated events will not be either repeatable or similar to those of spontaneous cycles.

There was a significant difference between the induced and spontaneous cycles in the timing of the onset of the first cornification peak relative to the first day of increased plasma progestagen. The earlier onset of cornification in the induced cycles may be related to the abnormal oestrogen profiles. The regimen of Arnold et al. (1989) was used because these workers had found that longer periods of equine chorionic gonadotrophin treatment resulted in hyperoestrogenism. The results of the present study show that excessive oestrogen production may occur even with this regimen. This could have been due, in part, to differences in the potency of preparations of equine chorionic gonadotrophin, or related to the oestrogen assays.

The degree of vaginal cell cornification was significantly less in the induced than in the spontaneous cycles; this is difficult to explain because oestrogen concentrations were generally greater, but similar findings were reported by Leathem \& Morrell (1939). Progestagen concentrations following induction were low, and mean values 5 days after the initial progestagen rise were lower (although not significantly) than for spontaneous cycles. This has been reported previously (Jones et al., 1973), and may be related to the small size and short lifespan of corpora lutea formed after such treatment (Bell \& Christie, 1971; Jones et al., 1973; Barta et al., 1982).

Fertility was not assessed in the present study, although in induced cycles high oestrogen concentrations might prevent implantation, and low progestagen concentrations might be insufficient to support pregnancy. This method of oestrus induction appears to be pharmacological and does 
not produce repeatable physiological events. Despite these problems, Arnold et al. (1989), using the same regimen, achieved pregnancy in three of six bitches.

We thank A. Young and S. Hellens for technical and nursing assistance, D. Porter for performing the hormone assays, G. Eyre for preparing the histological sections and D. Gunn for preparing the figures. Intervet UK provided the hormone preparations. G. C. W. England was in receipt of the Thomas Brown Research Fellowship.

\section{References}

Allen, W.E. (1982) Attempted oestrus induction in four bitches using pregnant mare serum gonadotrophin. $J$. small Anim. Pract. 23, 223-231.

Archbald, L.F., Baker, B.A., Clooney, L.L. \& Godke, R.A. (1980) A surgical method for collecting canine embryos after induction of estrus and ovulation with exogenous gonadotrophins. Vet. Med. \& small Anim. Clin. 75, 228-238.

Arnold, S., Arnold, P., Concannon, P.W., Weilenmann, R., Hubler, M., Casal, M., Dobeli, M., Eggenberger, E. \& Rusch, P. (1989) Effect of duration of PMSG treatment on induction of oestrus, pregnancy rates and the complications of hyper-oestrogenism in dogs. J. Reprod. Fert. Suppl. 39, 115-122.

Auskova, M., Rezabek, K., Zikan, V. \& Semonsky, M. (1974) Induction of oestrus and ovulation with an ergoline derivative, substance VUFB 6638, an inhibitor of prolactin secretion. Physiologia bohemoslov. 23, 417-421.

Barta, M., Archibald, L.F. \& Godke, R.A. (1982) Luteal function of induced corpora lutea in the bitch. Theriogenology 18, 541-549.

Bell, E.T. \& Christie, D.W. (1971) Gonadotrophin induced ovulation in the bitch. Proc. VII Wrld. Cong. Fert. Steril. 89, 26.

Cain, J.L., Lasley, B.L., Cain, G.R., Feldman, E.C. \& Stabenfeldt, G.H. (1989) Induction of ovulation in bitches with pulsatile or continuous infusion of GnRH. J. Reprod. Fert. Suppl. 39, 143-147.

Carter, J.G. (1980) Hormone treatment for nonproductive bitches. Can. vet. J. 21, 185.

Chakraborty, P.K., Wildt, D.E. \& Seager, S.W.J. (1982) Induction of estrus and ovulation in the cat and dog. Vet. Clins. Nrth. Am. (Small Anim. Pract.) 12, 85-92.

Challis, J.R.C., Heap, R.B. \& Illingworth, D.V. (1971) The plasma concentrations of oestrogen in non-pregnant, pregnant and lactating guinea pigs. J. Endocr. 51, 333-337.

Christie, D.W. \& Bell, E.T. (1971) Some observations on the seasonal incidence and frequency of oestrus in breeding bitches in Britain. J. Biol. Standard. 10, 1-8.

Cockrill, T. \& Allen, W.E. (1978) Diurnal variation of plasma progestagen concentrations in pony mares. Vet. Rec. 102, 503.

Concannon, P.W. (1989) Induction of fertile oestrus in anoestrus dogs by constant infusion of $\mathrm{GnRH}$ agonists. J. Reprod. Fert. Suppl. 39, 149-160.

Einer-Jensen, N. (1967) Induction of ovulation by bis (p-acetoxyphenyl) cyclohexlidenemethane (F60660) in the dog. Nord. VetMed. 19, 236-239.
England, G.C.W. \& Allen, W.E. (1989) Crystallization patterns in anterior vaginal fluid from bitches in oestrus. J. Reprod. Fert. 86, 335-339.

England, G.C.W., Allen, W.E. \& Blythe, S.A. (1989) Variability of the time of calculated LH release in 218 canine pregnancies. Vet. Rec. 125, 624-625.

Greenblatt, R.B. \& Pund, E.R. (1941) The gonadotrophins: a clinical and experimental study. Southern Med. 36, 730-742.

Hancock, J.L. \& Rowlands, I.W. (1949) The physiology of reproduction in the dog. Vet. Rec. 61, 771 .

Ishihara, M., Kita, I., Honjo, H. \& Hitazawa, K. (1982) Clinical studies on the artificial estrus of bitches. I Comparisons of artificial oestrus with natural oestrus. Res. Bull. Fac. Agr. Gifu Univ. 46, 249-256.

Jones, G.E., Boyns, A.R., Bell, E.T., Christie, D.W. \& Parkes, M.F. (1973) Immunoreactive luteinizing hormone and progesterone during pregnancy and following gonadotrophin administration in beagle bitches. Acta Endocr. 72, 573-581.

Leathem, J.H. \& Morrell, J.A. (1939) Induction of mating in the dog with pregnancy urine extract. Endocrinology 24, 149-156.

Moses, D.L. \& Shille, V.M. (1988) Induction of estrus in greyhound bitches with prolonged idiopathic anestrus or with suppression of estrus after testosterone administration. J. Am. vet. Med. Ass. 192, 1541-1545.

Nakao, T., Aoto, Y., Fukushima, S., Moriyoshi, M. \& Kawata, K. (1985) Induction of estrus in bitches with exogenous gonadotrophins, and pregnancy rate and blood progesterone profiles. Jap. J. vet. Sci. 47, $17-24$.

Papanicolaou, G.N. \& Blau, N.F. (1927) Existence of a sexual rhythm and experimental induction of heat in the dog during anoestrus. Anat. Rec. 35, 47.

Renton, J.P., Munro, C.D., Heathcote, R.H.\& Carmichael, S. (1981) Some aspects of the aetiology, diagnosis and treatment of infertility in the bitch. J. Reprod. Fert. 61, 289-294.

Rowlands, I.W. (1950) Some observations on the breeding of dogs. Proc. Conf. Soc. Study Fertil., Lond. 2, 40-55.

Scorgie, N.J. (1939) The treatment of sterility in the bitch by the use of gonadotrophic hormones. Vet. Rec. 51, 265-268.

Shille, V.M., Thatcher, M.J., Lloyd, M.L., Miller, D.D., Seyfert, D.F. \& Sherrod, J.D. (1989) Gonadotrophic control of follicular development and the use of exogenous gonadotrophins for induction of oestrus and ovulation in the bitch. J. Reprod. Fert. Suppl.39, 103-113. 
Thun, R., Watson, P. \& Jackson, G.L. (1977) Induction of estrus and ovulation in the bitch using exogenous gonadotrophins. Am. J. vet. Res. 38, 483-486.

Toniollo, G.H. \& Ferreira, H.I. (1984) Administracau de gonadotropina serica de egua prehe (PMSG) e gonadotropina corionica humana (hCG), na induacau de estro em cadelas. Arq. Bras. Med. vet. Zoot. 36, 613-616.

Van der Holst, W. \& Best, A.P. (1976) Een beschouwing over het meest geschikre tijdstip voor de dekking de teef. Tijdschr. Diergeneesk. 19, 125-133.

Vanderlip, S.L., Wing, A.E., Felt, P., Linke, D., Rivier, J., Concannon, P.W. \& Lasley, B.L. (1987) Ovulation induction in anestrous bitches by pulsatile administration of gonadotrophin releasing hormone. Lab. Anim. Sci. 37, 459-464.
Wildt, D.E., Chakraborty, P.K., Panko, W.B. \& Seager, S.W.J. (1978) Relationship of reproductive behavior, serum luteinizing hormone and time of ovulation in the bitch. Biol. Reprod. 18, 561-570.

Wright, P.J. (1972) A study of the response of the ovaries of bitches to pregnant mare serum (PMS) and human chorionic gonadotrophin (hCG). Proc. 7th Int. Cong. Anim. Reprod. AI. 2, 1075-1079.

Wright, P.J. (1980) The induction of oestrus and ovulation in the bitch using pregnant mare serum gonadotrophin and human chorionic gonadotrophin. Aust. vet. J. 56, 137-140.

Wright, P.J. (1982) The induction of oestrus in the bitch using daily injections of pregnant mare serum gonadotrophin. Aust. vet. J. 59, 123-124.

Received 8 November 1990 